\title{
SHORT PROOF THAT THE ARITHMETIC MEAN IS GREATER THAN THE HARMONIC MEAN AND ITS REVERSE INEQUALITY
}

\author{
TAKAYUKI FURUTA
}

Abstract. We shall give a short proof of the well known result made in its title.

Mathematics subject classification (2000): 47A63.

Key words and phrases: Arithmetic mean, harmonic mean.

REFERENCES

[1] T. Furuta, J. MićIć, J. PeČARIĆ AND Y. SEO, Mond-Pečarić Method in Operator Inequalities, Element, Zagreb, 2005. 